\title{
Analysis of Strata Stress and Its Effect on Lower-level Seam Exploitation under Room-and-pillar Shallow Coal Mining
}

\author{
Zuoqing Bi ${ }^{1}$, Jun Han ${ }^{1}$, Bing Liang ${ }^{1}$, Bingjie Huo ${ }^{1}$, Chen $\mathrm{Cao}^{1,2, *}$ and Shuangwen $\mathrm{Ma}^{1}$ \\ ${ }^{1}$ College of Mining Engineering, Liaoning Technical University, Fuxin123000, China \\ ${ }^{2}$ School of Civil, Mining and Environmental Engineering, University of Wollongong, Wollongong 2522, Australia
}

Received 12 December 2020; Accepted 3 March 2021

\begin{abstract}
To investigate the stress characteristics of the strata of coal 2-2 and its impact on the coal 3-1 exploitation under roomand-pillar shallow coal mining in Huoluowan coal mine of China, the theoretical, numerical and physical-modelling approaches were employed. The strata of coal 2-2 were categorized into four types, namely, stable, unstable, $20 \mathrm{~m}$ and $50 \mathrm{~m}$ coal pillars, respectively. The stress fields corresponding to various types of underlaying strata were revealed and the influence on the coal 3-1 mining was analyzed and verified by the physical model experiment. Results show that the stress of coal 3-1 is in the pressure-relief state under the stable and unstable pillars, $8 \%$ to $14.3 \%$ decreases of the initial vertical pressure. The vertical stress in coal 3-1 increases $5 \%$ to $32 \%$ under the $20 \mathrm{~m}$ and $50 \mathrm{~m}$ coal pillars, respectively. The periodic caving length of roof of coal 3-1 is $12 \mathrm{~m}$ to $14 \mathrm{~m}$ under the stable and unstable pillars, but it is $10 \mathrm{~m}$ to $11 \mathrm{~m}$ under the $20 \mathrm{~m}$ and $50 \mathrm{~m}$ coal pillars. The physical modelling demonstrates that the coal 3-1 is ejected when that is mined below the $20 \mathrm{~m}$ and $50 \mathrm{~m}$ coal pillars. The obtained conclusions have applicability in reference to the similar practice.
\end{abstract}

Keywords: Shallow coal mining, Room-and-pillar, Abutment pressure, Periodic caving, Strata structure

\section{Introduction}

Room-and-pillar coal mining is a professional coal mining method, and it is a kind of pillar system coal mining. During coal mining, the coal pillars of different shapes are reserved in the coal room, and the coal pillars temporarily support the roof in the coal mining. After the coal room is mined, the reserved coal pillars will be recovered in a planned manner. The pillar system mining is widely used in the United States, Australia, Canada, India, South Africa, and other countries.

The bearing capacity of the roof of shallow-buried coal seam is often small. Consequently, the overlaying strata cave synchronously with surface subsidence [1]. Overlaying strata caving and ground stress change may lead remarkable dynamic pressure [2]. For the mining of multiple coal seams, many scholars have conducted researches on the influence of the stress field formed by the upper coal in strip mining on the lower coal. However, there are few studies on how the stress field formed after room-and-pillar mining of the upper coal is transferred to the lower coal through the coal pillar, and how the transfer stress of the coal pillar changed during the lower coal mining [3-4].

Therefore, it is very important to investigate the stress characteristics of the strata of the upper coal mining and its impact on the lower coal exploitation [5-7]. This study intends to combine the actual engineering to reveal the evolution process of the complex stress field formed by room-and-pillar multi-layer coal mining, and the mechanism that leads to the failure of the lower coal pillar, which can provide the theoretical and technical basis for guiding the engineering practice.

\footnotetext{
*E-mail address: 2065214306@qq.com

ISSN: 1791-2377 @ 2021 School of Science, IHU. All rights reserved. doi:10.25103/jestr.141.08
}

\section{State of the art}

Numerous studies have been conducted to investigate the ground stress transfer of the coal pillar and overlaying strata movement of lower seam in multiple coal seams mining by using different methods [8-11].

For examples, $\mathrm{Li}$ et al. explored the stress transfer of the coal pillar through theoretical and numerical approaches [12] Andre \& Anderson simulated the pillar retreat and ground movement in a three-dimensional numerical model [13]. Kim et al. analyzed the design parameters of the room-andpillar mining using numerical methods [14]. Kalenchuk et al. evaluated the geomechanical, operational, safety and economical risks before developing a comprehensive plan to extract the Santo Niño crown pillar by underground stoping [15]. Zhang et al. investigated the stress transfer between the coal pillar group to floor strata using improved matrix force method and numerical simulation [16]. Michail et al. presented the design of the mining scheme in detail along with the building of the $3 \mathrm{D}$ numerical model which simulated the overall development of the pilot mine [17].

Gamal et al. monitored the deformation and the stress change in an instrumented pillar during the progress of pillar retreat mining at two sites of different geological conditions and depths of cover. They want to better understand the stress transfer and load shedding on coal pillars and to quantify the rib deformation due to pillar retreat mining [18]. Westman, et al. conducted several monitoring methods including a seismic monitoring system, borehole pressure cells in the pillars, and time-lapse photogrammetry of the pillar ribs to study pillar and overburden response to retreat mining [19]. Yang calculated the mining heights with or without reinforcement based on breakage and movement of the key stratum of the roof in shallow-buried coal seam mining [20]. Yang et al. revealed the progressive breakage 
of the overlying strata when mining close-distanced coal seams using room-and-pillar method through analyzing the roof deformation gradient and enhanced image algorithm methods [21].

However, there are few reports on how the stress field caused by room-and-pillar mining is transmitted through coal pillars. So this study investigates the overlaying strata structure of coal 3-1 which is under the coal 2-2 in the Huoluowan coal mine. Four types of the overburden structures of coal 3-1 are classified, namely, stable, unstable, $20 \mathrm{~m}$ and $50 \mathrm{~m}$ coal pillars, respectively. The stress field corresponding to each overburden structure and its influence on the abutment pressure of the coal 3-1 are investigated using theoretical, numerical and physical-modeling methods.

The rest of this study is organized as follows. Section 3 gives the relevant background and describes the theoretical, numerical and physical-modeling methods. Section 4 presents the experimental results and related discussion. Finally, the conclusions are summarized in Section 5.

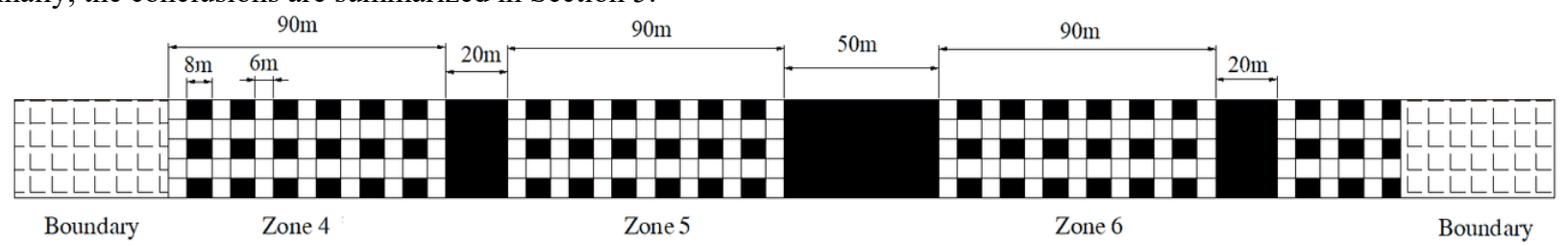

Fig. 1. Coal pillars in coal 2-2.

Table 1. Mechanical parameters of coal 2-2 and 3-1.

\begin{tabular}{|c|c|c|c|c|c|c|}
\hline Name & $\begin{array}{c}\text { Thickness } \\
(\mathrm{m})\end{array}$ & $\begin{array}{c}\text { Volume force } \\
\left(\mathrm{kN} / \mathrm{m}^{3}\right)\end{array}$ & $\begin{array}{c}\text { Tensile strength } \\
(\mathrm{MPa})\end{array}$ & $\begin{array}{c}\text { Cohesion } \\
(\mathrm{MPa})\end{array}$ & $\begin{array}{c}\text { Bulk modulus } \\
(\mathrm{GPa})\end{array}$ & $\begin{array}{c}\text { Shear modulus } \\
(\mathrm{GPa})\end{array}$ \\
\hline Sandy mudstone & 1.51 & 23.3 & 2.18 & 3.82 & 6.12 & 4.21 \\
\hline Coal 2-2 & 5.36 & 14.7 & 0.82 & 2.64 & 1.60 & 0.67 \\
\hline Mudstone & 4.21 & 23.8 & 1.58 & 3.55 & 4.35 & 2.73 \\
\hline Sandy mudstone & 2.09 & 23.3 & 2.18 & 3.82 & 6.12 & 4.21 \\
\hline $\begin{array}{c}\text { Fine-grained } \\
\text { sandstone }\end{array}$ & 2.54 & 23.53 & 1.95 & 2.96 & 6.02 & 3.97 \\
\hline Sandy mudstone & 4.7 & 23.3 & 2.18 & 3.82 & 6.12 & 4.21 \\
\hline $\begin{array}{c}\text { Fine-grained } \\
\text { sandstone }\end{array}$ & 11.71 & 23.53 & 1.95 & 2.96 & 6.02 & 3.97 \\
\hline Siltstone & 7.86 & 22.09 & 4.24 & 2.94 & 5.26 & 3.46 \\
\hline Sandy mudstone & 1.88 & 23.3 & 2.18 & 3.82 & 6.12 & 4.21 \\
\hline Coal 3-1 & 4.16 & 14.7 & 0.82 & 2.64 & 3.60 & 2.67 \\
\hline Mudstone & 1.94 & 23.8 & 2.18 & 35 & 4.35 & 2.73 \\
\hline
\end{tabular}

The inclose distance multiple coal seams were mined by using room-and-pillar method. The overburden structure of the lower seam was mainly determined by the conditions of the upper seam pillar. The overburden pressure was transferred to the overlaying strata of the lower seam via the left pillars in the upper seam. Consequently, the ground pressure of overlaying strata of the coal 3-1 and abutment pressure of the working face relyed on the interaction of the pillar with its surrounding strata. As the stress field was complicated due to different pillar structures, the risk of coal 3-1 mining was high.

The rib of the pillars was subjected to the concentrated load leading plastic deformation initially. Along with the

\section{Methodology}

\subsection{Engineering background}

The bury depth of coal 2-2 in the Huoluowan coal mine was $148 \mathrm{~m}$ and the room-and-pillar mining method was employed. The room width was $6 \mathrm{~m}$ and the pillar width was $8 \mathrm{~m}$, i.e., $6 \mathrm{~m}$ width coal was mined with $8 \mathrm{~m}$ coal pillar left. The mining height was $4 \mathrm{~m}$. To prevent massive roof collapse, the area of each mining zone was restricted to less than $10000 \mathrm{~m}^{2}$. Normally, the width of one mining zone was $90 \mathrm{~m}$ and two adjective mining zones were separated by coal pillar of $20 \mathrm{~m}$ or $50 \mathrm{~m}$ width, as shown in Fig. 1.

The coal 3-1 was $30 \mathrm{~m}$ below the coal 2-2. The dip angle of the coal $3-1$ was $0^{\circ}$ to $3^{\circ}$ with a thickness from $0.88 \mathrm{~m}$ to $4.67 \mathrm{~m}$. The average thickness was $3.86 \mathrm{~m}$. The roof and floor of two seams were mainly comprised of sandy mudstone and mudstone. Table 1 illustrates the physical and mechanical properties of the strata.

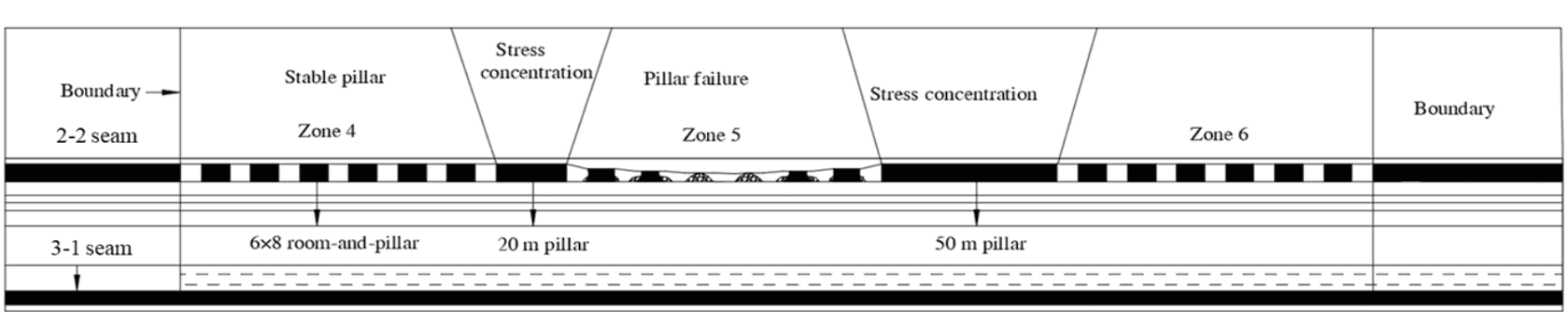

Fig. 2. Overburden structure classification in the Huoluowan coal mine.

development of the plastic region, small coal pillar failed completely. Field investigation suggested that the $20 \mathrm{~m}$ and $50 \mathrm{~m}$ coal pillars were stable as there was no noticeable surface subsidence. The pillars of mining zone 4 were most likely stable since the ground above this area did not exhibit noticeable subsidence. However, the ground surface above the fifth zone experienced severe subsidence, indicating that the pillars in this zone were failed completely. Therefore, the overlaying strata structure of the coal 3-1 were classified into four types based on coal 2-2 pillar conditions, namely, stable, unstable, $20 \mathrm{~m}$ and $50 \mathrm{~m}$ coal pillars, respectively (Fig. 2). 
3.2 Theoretical method of floor stress calculation. The vertical stress distribution under coal pillar can be calculated as:

$$
\eta=-\frac{q}{2 \pi}\left[2\left(\theta_{2}-\theta_{1}\right)+\left(\sin 2 \theta_{2}-\sin 2 \theta_{1}\right)\right]
$$

where, $\sigma$ is the vertical stress of point $\mathrm{A}, \theta_{1}$ and $\theta_{2}$ are the angles between $\mathrm{A}$ and two boundaries of the pillar. The geometrical relationship of the stress analysis is shown in Fig. 3. Accordingly, the following formulation can be used to determined the relationship between the coordinates of point $\mathrm{A}\left(x_{A}, y_{A}\right)$ and $\theta_{1}$ and $\theta_{2}$, respectively:

$$
\theta_{1}=\arctan \frac{y_{A}-a}{x_{A}}, \quad \theta_{2}=\arctan \frac{y_{A}-b}{x_{A}}
$$

where, $a$ and $b$ represent the distance of the coordinate origin to right and left boundaries of the pillar, respectively.

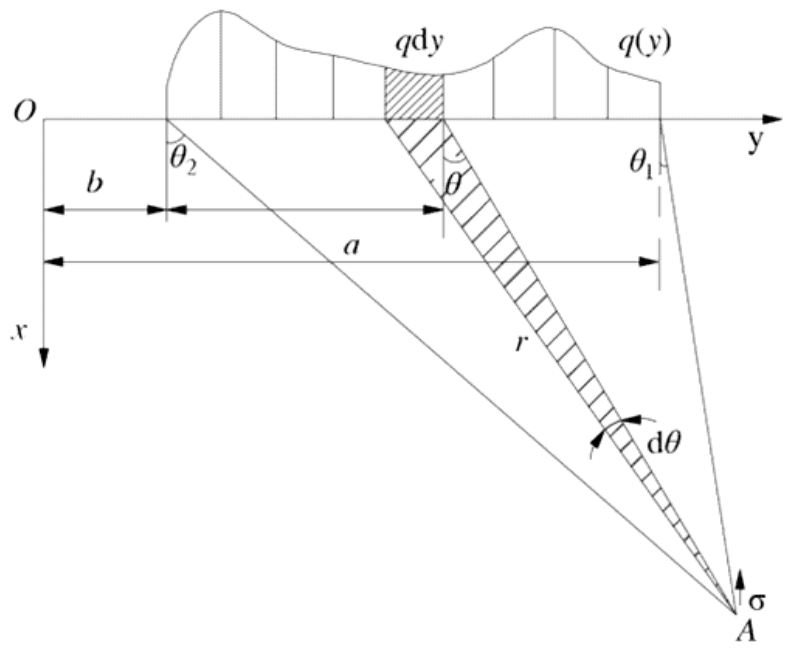

Fig. 3. Stress transfer model of the coal pillar.

\subsection{Physical model}

According to the similarity criterion of the physical modelling, the geometry similarity was established as 100:1, and the density similarity was $1.5: 1$, that is, the unit weight of the real strata was $2.4 \mathrm{~g} / \mathrm{m}^{3}$ and the unit weight of the physical model is $1.8 \mathrm{~g} / \mathrm{m}^{3}$ [22-23]. The size of the physical model is $5000 \mathrm{~mm} \times 300 \mathrm{~mm} \times 2000 \mathrm{~mm}$ (length $\times$ width $\times$ height). The monitoring points were arranged below the overburden, indicated by the blue dots in Fig. 4. As the coal 2-2 and 3-1 were shallow-buried, the whole strata was included. Therefore, no loading was applied on the top of the model.

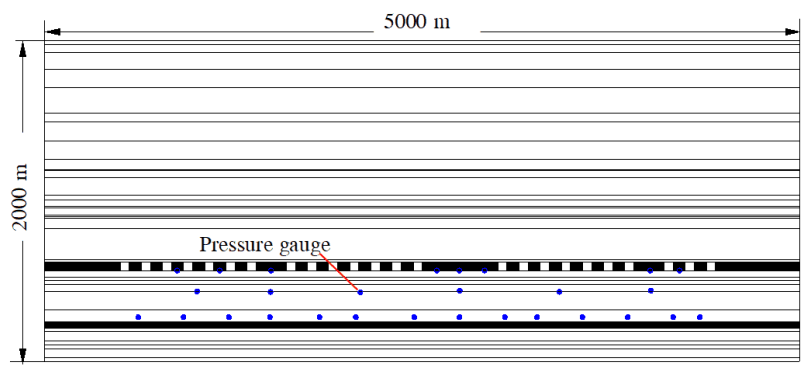

Fig. 4. Dimension and stress monitoring of the physical model.

In the physical model, the paraffin was melt to simulate the stable-room-pillar overburden structure. The unstableroom-pillar overburden structure was induced through mining the room area and then manually broke the pillars. As illustrated in Fig. 5, the $20 \mathrm{~m}$ and $50 \mathrm{~m}$ coal pillars were set according to the scale.

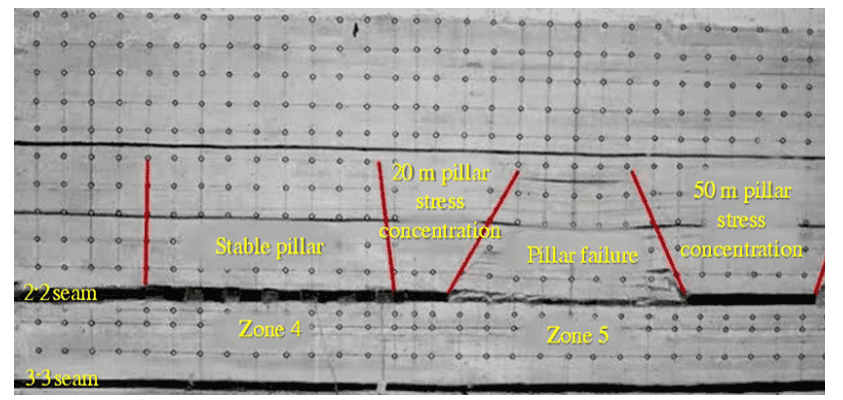

Fig. 5. The diagram of the physical model.

\subsection{The computational model}

The numerical model was constructed according to the field geological conditions of the Huoluowan coal mine. The ground stress while mining the coal 3-1 was also numerically studied by using FLAC3D [24]. Considering the real layout of the seams as well as the boundary effect, the dimension of the numerical model was established as $500 \mathrm{~m}$ $\times 400 \mathrm{~m} \times 200 \mathrm{~m}$ (length $\times$ width $\times$ height), in which the width of the boundary coal pillars was $50 \mathrm{~m}$.

In the model, the displacements along $X$ - and $Y$-direction were fixed at two boundaries. The bottom of the model was fixed, the top of the model was free, and the gravitational load was applied along $Z$-direction. Based on the in-situ stress measurement, the initial stress $4.6 \mathrm{MPa}, 2.2 \mathrm{MPa}$ and 3.6 MPa were applied along $X-, Y$ - and Z-direction, respectively. The numerical model was initialized to the premining condition, then, the coal 2-2 and 3-1 were excavated.

\section{Results and discussion}

\subsection{Analysis of floor stress field}

Based on Eqs. (1) and (2), the stress fields of four types of overburden structures can be calculated through MATLAB, as shown in Fig. 6. The influential depth of the vertical stress of the stable-room-pillar, $20 \mathrm{~m}$-coal-pillar, unstable-roompillar and the $50 \mathrm{~m}$-coal-pillar are $12-15 \mathrm{~m}, 36 \mathrm{~m}, 3-5 \mathrm{~m}$ and $44 \mathrm{~m}$, respectively. The stable pillar has less influence on the stress field of the lower seam comparing with that of the $20 \mathrm{~m}$ and $50 \mathrm{~m}$ coal pillars, which pose pronounced impact while coal 3-1 being mined.

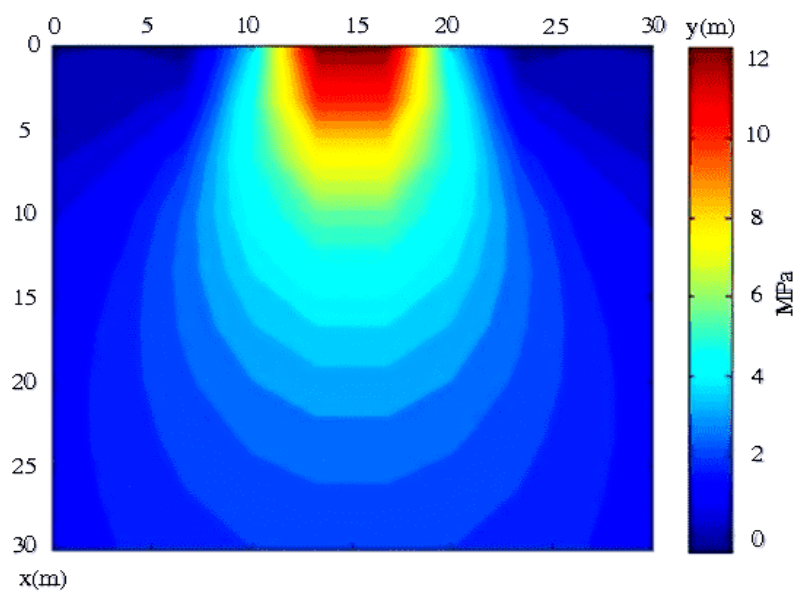

(a) Stable pillar 
Zuoqing Bi, Jun Han, Bing Liang, Bingiie Huo, Chen Cao and Shuangwen Ma/

Journal of Engineering Science and Technology Review 14 (1) (2021) 79 - 85

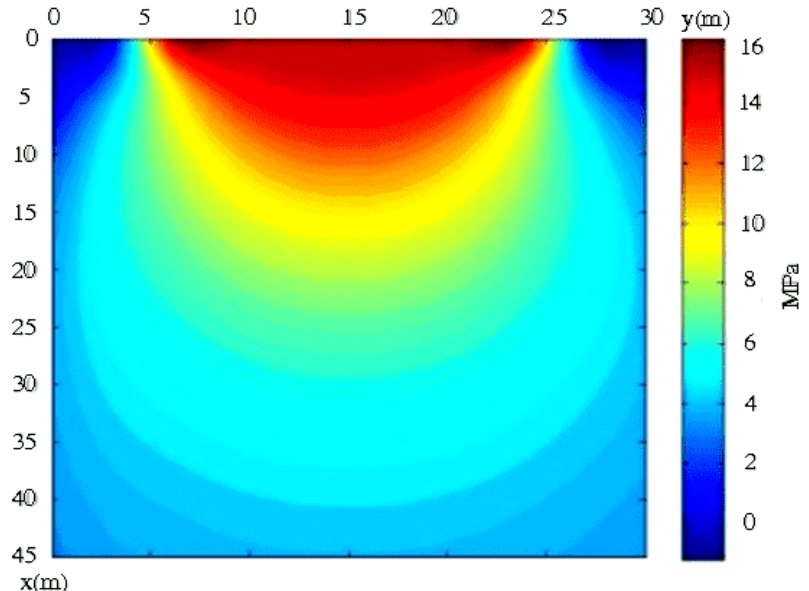

(b) $20 \mathrm{~m}$ coal pillar

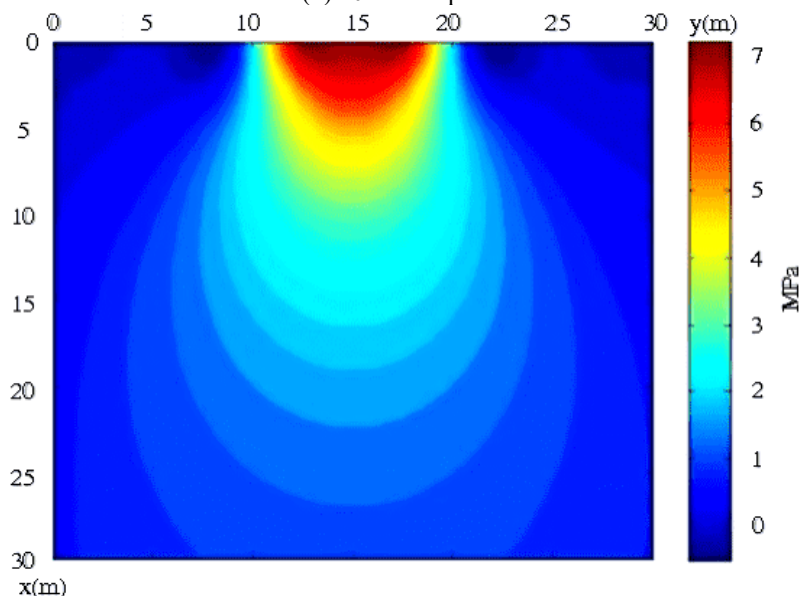

(c) Unstable pillar

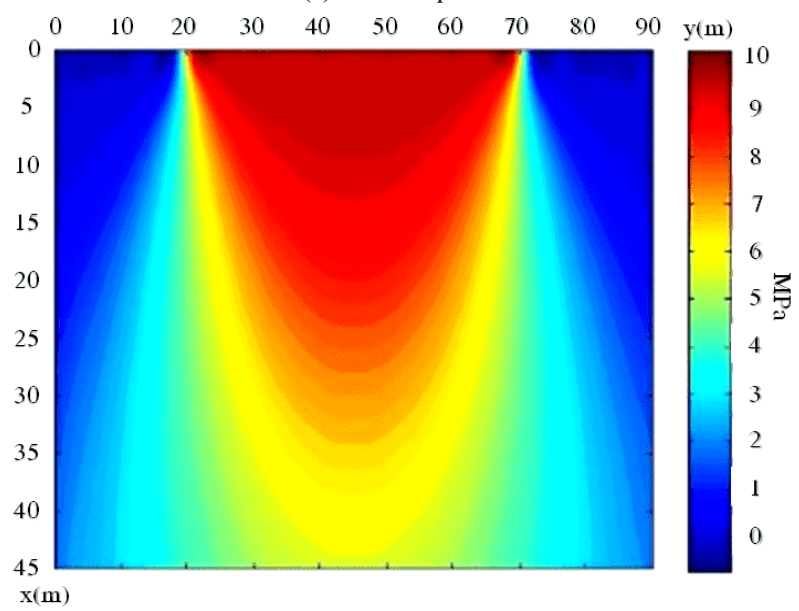

(d) $50 \mathrm{~m}$ coal pillar

Fig. 6. Floor stress distribution of the coal pillar of different overburden structures.

\subsection{Stress analysis of different overburden structures}

After the coal 2-2 was mined out, the ground stress was different for different types of the overburden structures. Table 2 lists the monitoring results of the pressure gauges. The initial vertical stress at the location of $15 \mathrm{~m}$ below the coal pillar was 3.9 MPa. Their stresses were $-12 \%,+28 \%$, $10 \%$ and $+20 \%$ under the stable-room-pillar, $20 \mathrm{~m}$-coalpillar, unstable-room-pillar and $50 \mathrm{~m}$-coal-pillar structures, respectively. The initial stress of the model at the point $30 \mathrm{~m}$ below the coal pillar, i.e., the roof of the coal 3-1, is 4.48 MPa. The stresses were $-8 \%,+15 \%,-6 \%$ and $+8 \%$ under the stable-room-pillar, $20 \mathrm{~m}$-coal-pillar, unstableroom-pillar, and $50 \mathrm{~m}$-coal-pillar structures, respectively.
Table 2. Vertical stress changes at different positions in the model.

\begin{tabular}{c|c|c}
\hline \multirow{2}{*}{ Name } & \multicolumn{2}{|c}{ Stress at different positions (MPa) } \\
\cline { 2 - 3 } & $\mathbf{1 5}$ m below & The roof of the \\
\hline Stable-room-pillar & 3.43 & 4.12 \\
20 m-coal-pillar & 4.99 & 5.15 \\
Unstable-room-pillar & 3.51 & 4.21 \\
50 m-coal-pillar & 4.68 & 4.84 \\
\hline
\end{tabular}

\subsection{Effect of overburden structure on the lower seam} mining

The physical modeling showed that under the stable-roompillar overburden structure, the main roof underwent the first breakage (denoted by (1)) when the working face was advanced to $32 \mathrm{~m}$. When the advancing distances were $46 \mathrm{~m}$, $62 \mathrm{~m}$ and $74 \mathrm{~m}$, the periodic caving length was $12-14 \mathrm{~m}$. The caving height was $30 \mathrm{~m}$ (Fig. 7).

Below the $20 \mathrm{~m}$ coal pillar, the periodic stress concentration occurred while the working face advanced to $90 \mathrm{~m}, 100 \mathrm{~m}$ and $111 \mathrm{~m}$, i.e., the periodic caving length was $10-11 \mathrm{~m}$. The blocks of broken overburden strata were relatively large. When the working face was advanced to $111 \mathrm{~m}$, the fractures over the goaf propagated to the surface. The coal was ejected out when the working face passed the coal pillar (Fig. 8).

Under the unstable-room-pillar overburden structure, the periodic pressure occurred when the working face was advanced to $144 \mathrm{~m}, 156 \mathrm{~m}, 169 \mathrm{~m}$ and $182 \mathrm{~m}$. The periodic caving length was $12-13 \mathrm{~m}$. The height of caved roof increased with the high ground stress (Fig. 9).

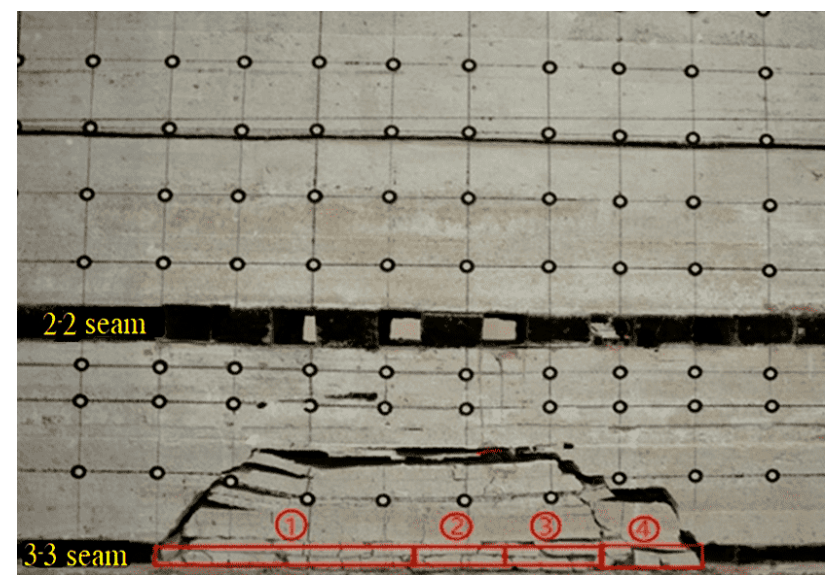

Fig. 7. Overburden movement of coal 3-1 under stable-room-pillar.

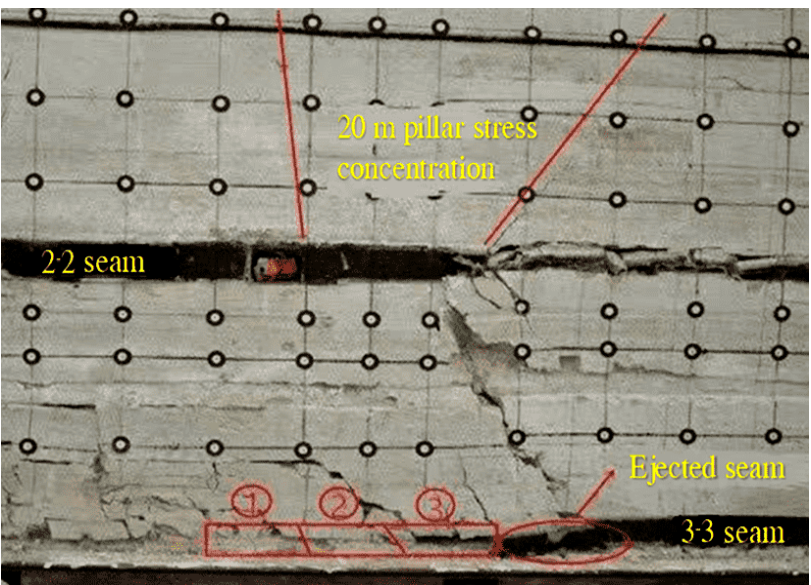

Fig. 8. Overburden movement of coal 3-1 under 20 m-coal-pillar. 


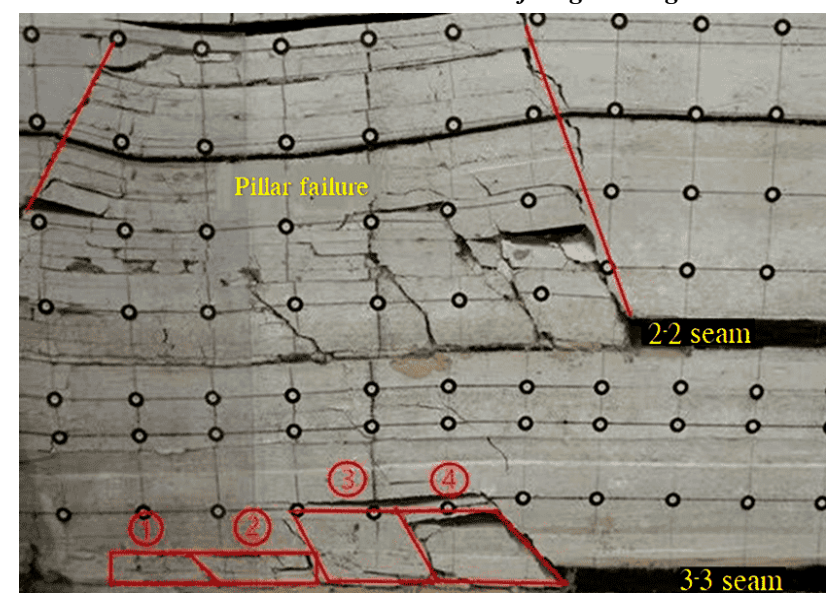

Fig. 9. Overburden movement of coal 3-1 under unstable-room-pillar.

The strata caving can be as a whole under the $50 \mathrm{~m}$-coalpillar. The high periodic pressure was measured when the working face advanced to $206 \mathrm{~m}, 217 \mathrm{~m}, 234 \mathrm{~m}$ and $244 \mathrm{~m}$, indicating the periodic caving length of $10-11 \mathrm{~m}$. When the working face was advanced to $244 \mathrm{~m}$, the fractures over the unmined coal propagated to the surface. The coal in the working face was ejected out. Therefore, the effective measures should be undertaken to mitigate the dynamicpressure associated disasters when mining the coal 3-1 area below the $50 \mathrm{~m}$ coal pillar (Fig. 10).

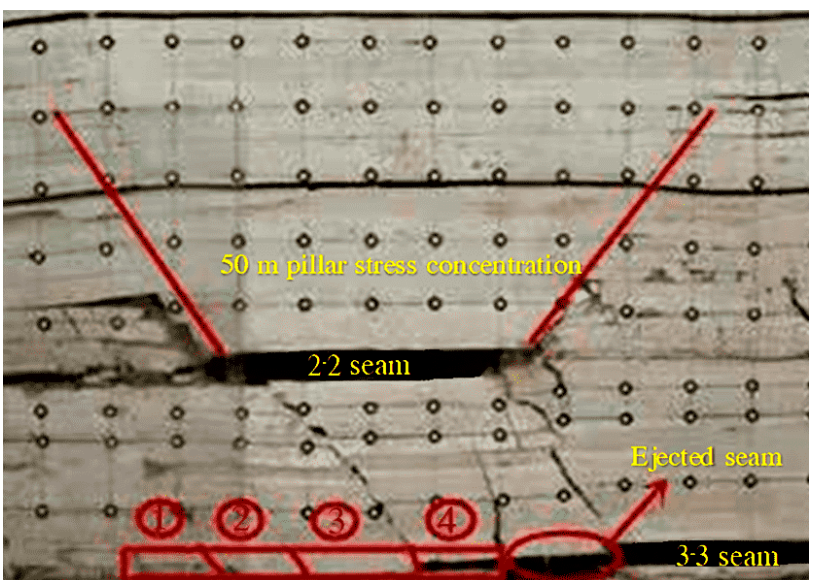

Fig. 10. Overburden movement of coal 3-1 under 50 m-coal-pillar.

\subsection{Stress field analysis after mining coal 2-2}

Fig. 11 shows the stress distribution of the surrounding rock after mining coal 2-2. The initial vertical stress of the coal 31 was $4.2 \mathrm{MPa}$. Before the coal pillar collapsed, the vertical stress of the coal 3-1 was 3.6 MPa, which declined by $14.3 \%$ under the stable overburden structure. After the coal pillar collapsed, the vertical stress of the coal 3-1 decreased to 3.7 MPa. The vertical stress increased at the areas below the $20 \mathrm{~m}$ and $50 \mathrm{~m}$ coal pillars. The stresses of the coal 3-1 increased by $5 \%-32 \%$ and $14 \%-28 \%$, respectively. It was consistent with the physical modeling results. Thus, the ground pressure monitoring and roof management should be implemented when mining the coal 3-1 at this area.

\subsection{Abutment pressure of coal 3-1 working face}

Fig. 12 demonstrates the abutment pressure obtained by monitoring the stress of the roof and coal in front of the working face. The abutment pressure slightly fluctuated due to room or pillar of coal 2-2. In the initial mining stage, the abutment pressure gradually increased, it reached to the maximum value while the working face passed through the $20 \mathrm{~m}$ coal pillar. Then, the abutment pressure decreased and became stable. The abutment pressure gradually increased as the working face passed through the $50 \mathrm{~m}$ coal pillar. Then it decreased. In the mining process, the vertical stress was lower than the initial value in the distance of 1-2 $\mathrm{m}$ ahead of the working face. But the stress was concentrated in the distance of $2-35 \mathrm{~m}$ ahead of the working face. The influenced region of the abutment pressure was $45-65 \mathrm{~m}$ with the peak value of $6.2 \mathrm{MPa}$ to $17.2 \mathrm{MPa}$ at the distance of 8-10 $\mathrm{m}$ ahead of the working face.
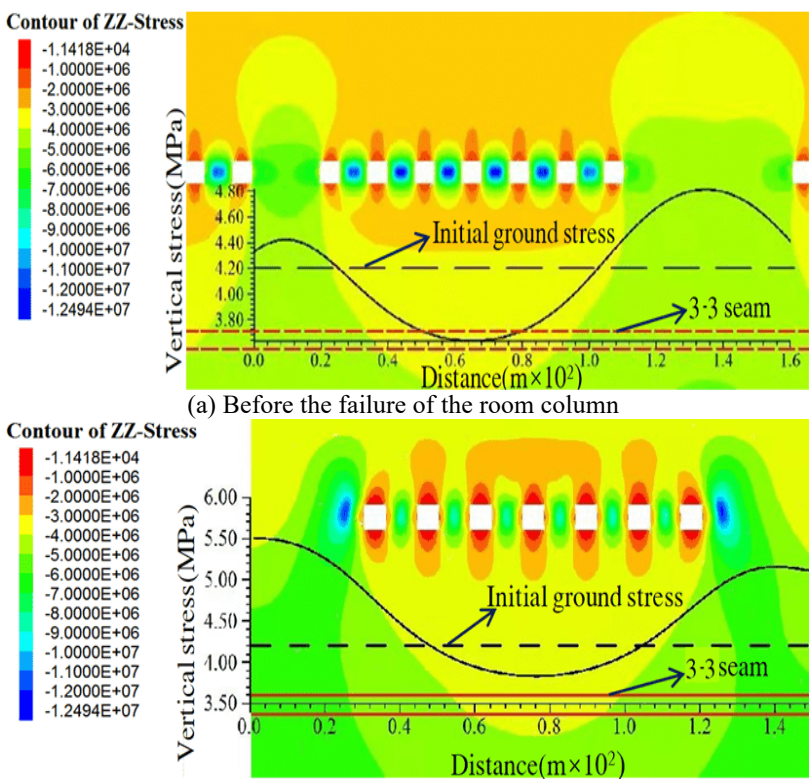

(b) After the failure of the room column

Fig. 11. Stress distribution of the surrounding rock after mining coal 2-2.

Due to the influence of the pillar, the ground stress below the $20 \mathrm{~m}$ coal pillar was higher than that of the $50 \mathrm{~m}$ coal pillar. The stress concentration factors of the abutment pressure of the working face were 2.76 and 3.62 respectively under the stable and unstable room-pillar overburden structures. The abutment pressure was maximum when the working face passed the $20 \mathrm{~m}$ and $50 \mathrm{~m}$ coal pillars, with stress concentration factors of 4.10 and 3.85, respectively. This explained the strong ground pressure when the working face passed the coal pillars in the physical modeling.

\section{Conclusions}

To investigate the stress characteristics of the strata of coal 2-2 and its impact on the coal 3-1 exploitation under roomand-pillar shallow coal mining in Huoluowan coal mine, the theoretical, numerical and physical-modelling approaches were employed. The following conclusions are drawn:

(1) The overburden structures of the shallow-buried coal 2-2 can be classified as four types, namely, stable-roompillar, unstable-room-pillar, $20 \mathrm{~m}$-coal-pillar, and $50 \mathrm{~m}$-coalpillar, respectively. The vertical stress of the coal 3-1 decreases by $6 \%$ to $14.3 \%$ under the stable- and unstableroom-pillar structures whereas the vertical stress increases by $5 \%$ to $32 \%$ under the $20 \mathrm{~m}$ and $50 \mathrm{~m}$ coal pillars. 


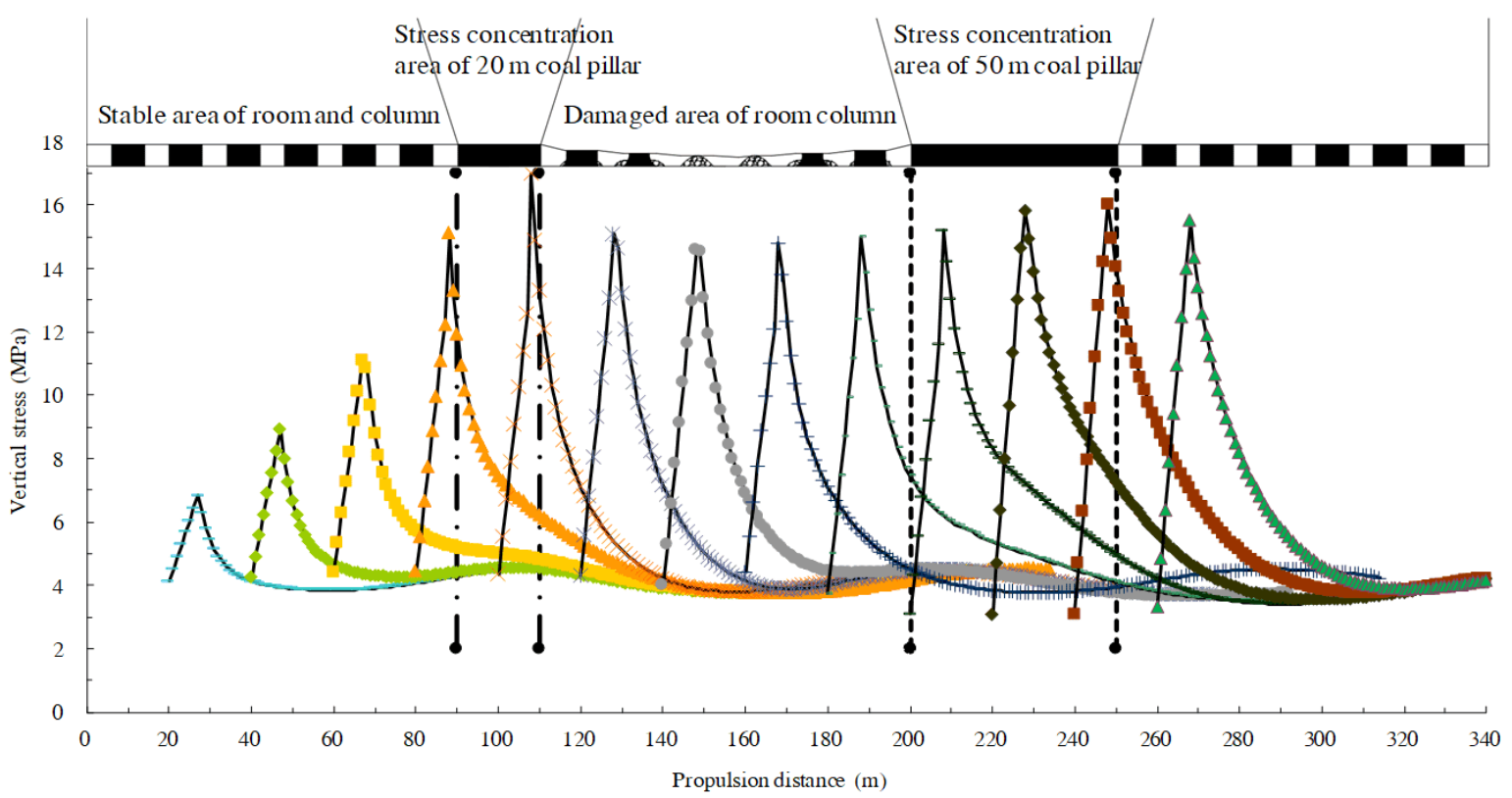

Fig. 12. Distribution of the advanced abutment pressure at different advancements of the working face of coal 3-1.

(2) The weighting distance of the coal 3-1 is $12-14 \mathrm{~m}$ under the stable and unstable room pillar structures, $10-11 \mathrm{~m}$ under the $20 \mathrm{~m}$ and $50 \mathrm{~m}$ coal pillars. The stress concentration factors of the abutment pressure under the four types of overburden structures are $4.10,3.85,2.76$ and 3.62 , respectively.

(3) The physical modeling shows that the coal is ejected when the coal $3-1$ is mined below the $20 \mathrm{~m}$ and $50 \mathrm{~m}$ coal pillars, suggesting that dynamic-pressure associated disasters may occur. Therefore, the ground pressure monitoring and roof management measures should be implemented.

The room-and-pillar mining method has such advantages: less equipment investment, short construction period, quick coal production, and higher efficiency. It is especially used in small and medium-sized mines. This study has carried out the research of two-layer coal mining and obtained many research results by using room-and-pillar mining method. The next step is to study the complex stress field of more than two-layers coal for room-and-pillar mining.

\section{Acknowledgements}

This work was financially supported by the National Natural Science Foundation of China (51774112), and the Fundamental Research Funds for the Universities of Henan Province (NSFRF200202), China.

This is an Open Access article distributed under the terms of the Creative Commons Attribution License.

\section{References}

1. Fan, G., Zhang, D., Ma, L., "Overburden movement and facture distribution induced by longwall mining of the shallow coal seam in the Shendong coalfield". Journal of China University of Mining \& Technology, 40(2), 2011, pp. 196-201.

2. Tu, S. H., Dou, F. J., Wan, Z. J., Wang, F., T., Yuan, Y., "Strata control technology of the fully mechanized face in shallow coal seam close to the above room and pillar gob". Journal of China Coal Society, 36(3), 2011, pp. 366-370.

3. Ren, Y., Qi, Q., "Study on characteristic of stress field in surrounding rocks of shallow coal face under long wall mining". Journal of China Coal Society, 36(10), 2011, pp.1612-1618.

4. Xie, X., "Study on the characteristics of strata behavior in shallow seam longwall mining under the room-and-pillar mining goaf". Journal of China Coal Society, 37(6), 2012, pp. 898-902.

5. Wang, S. R., Wu, X. G., Zhao, Y. H., Hagan, P., Cao, C., "Evolution characteristics of composite pressure-arch in thin bedrock of overlying strata during shallow coal mining". International Journal of Applied Mechanics, Article ID 1950030, 11(5), 2019, pp. 1-20.

6. Zhao, Y. H., Wang, S. R., Zou, Y. F., Wang, X. C., Huang, B. Q., Zhang, X. G., "Pressure-arching characteristics of fractured strata structure during shallow horizontal coal mining". Tehnicki VjesnikTechnical Gazette, 25(5), 2018, pp. 1457-1466.

7. Wang, S. R., Li, N., Li, C. L., Zou, Z. S., Chang, X., "Instability mechanism analysis of pressure-arch in coal mining field under different seam dip angles". Dyna, 90(3), 2015, pp. 279-284.

8. Pisačić, K., Horvat, M., Botak, Z., "Numerical simulation of the stress-strain state of complex-reinforced elements". Technical Journal, 13(3), 2019, pp. 241-247.
9. Luo, T., Wang, S.R., Zhang, C. G., Liu, X. L., "Parameters deterioration rules of surrounding rock for deep tunnel excavation based on unloading effect". Dyna, 92(6), 2017, pp. 648-654.

10. Wang, S. R., Li, N., Li, C. L., Hagan, P., "Mechanics evolution characteristics analysis of pressure-arch in fully-mechanized mining field". Journal of Engineering Science and Technology Review, 7(4), 2014, pp. 40-45.

11. Zhao, Y. H., Wang, S. R., Hagan, P., Guo, W. B., "Evolution characteristics of pressure-arch and elastic energy during shallow horizontal coal mining”. Tehnicki Vjesnik-Technical Gazette, 25(3), 2018, pp. 867-875.

12. Li, S., Zhou, L., Luo, M. K., Dong, H. D., Qi, X. X., "Strata behaviors analysis of stage coal pillar in Tong Xin mine caused by repeated mining". Journal of Liaoning Technical University (Natural Science Edition), 34(6), 2015, pp. 661-667.

13. Andre, Z., Anderson, W., "Subsidence over room and pillar retreat mining in a low coal seam". International Journal of Mining Science and Technology, 29(1), 2019, pp. 51-57.

14. Kim, J. G., Ali, M. A. M., Yang, H. S., "Robust design of pillar arrangement for safe room-and-pillar mining method". Geotechnical and Geological Engineering, 37(7), 2019, pp. 19311942.

15. Kalenchuk, K., Falmagne, V., Gelover, A., Montiel, I., Luzania, J., "Risk evaluation, design, implementation, instrumentation, and verification for crown pillar extraction at Pinos Altos Mine". Rock Mechanics and Rock Engineering, 52(12), 2019, pp. 4997-5011. 


\section{Zuoqing Bi, Jun Han, Bing Liang, Bingiie Huo, Chen Cao and Shuangwen Ma/}

Journal of Engineering Science and Technology Review 14 (1) (2021) 79 - 85

16. Zhang, S. K., Wang, L. G., Zhang, X. D., Song, K., "Load transfer effects of the longwall sustaining coal pillars on the safety of the mining goaf system". Journal of Safety and Environment, 16(3), 2016, pp. 116-119.

17. Michail. T., Ioannis, T., Andreas, B., Vassilis, M., "Room and pillar design and construction for underground coal mining in Greece". Geotechnical and Geological Engineering, 37(3), 2019, pp. 17291742 .

18. Gamal, A., Khaled, M., Robert, K., "A coal rib monitoring study in a room-and-pillar retreat mine". International Journal of Mining Science and Technology, 31(1), 2021, pp. 127-135.

19. Westman, E. C., Molka, R. J., Conrad, W. J., "Ground control monitoring of retreat room-and-pillar mine in Central Appalachia". International Journal of Mining Science and Technology, 27(1), 2017, pp. 65-69.

20. Yang, Z. L., "Instability of roof strata in shallow coal seam longwall mining”. Journal of China Coal Society, 33(12), 2008, pp. 13411345 .
21. Yang, Z., Tong, B., Huang, C. C., Wang, G., "Study on the movement law of overlying strata in mining face under room and pillar goaf'. Journal of Mining \& Safety Engineering, 29(2), 2012, pp. 157-161.

22. Yu, B., Liu, C. Y., Yang, J. X., Liu, J. R., "Mechanism of strong pressure reveal under the influence of mining dual system of coal pillar in Datong mining area". Journal of China Coal Society, 39(1), 2014, pp. 40-46.

23. Wang, Y. F., Wang, S. R., Li, Z., Jiao, H. Z., "Strength characteristics and empirical criterion of dry and saturated sandstone subjected to compression test". Journal of Engineering Science and Technology Review, 13(2), 2020, pp. 119-126.

24. Krantovska, O., Petrov, M., Ksonshkevych, L., Orešković, M., Synii, S., Ismailova, N., "Finite difference solution of plate bending using Wolfram Mathematica". Technical Journal, 13(2), 2019, pp. $110-115$. 